\title{
Reinforced concrete bridge pier ductility analysis for different levels of detailing
}

\section{Análise de dutilidade de pilar de ponte em concreto armado considerando diferentes niveis de detalhamento}
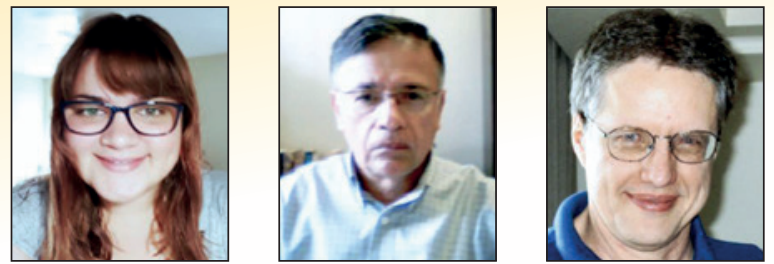

R. W. SOARES a rachelwysard@gmail.com

S. S. LIMA sdesouzalima@gmail.com

S. H. C. SANTOS sergiohamsphire@gmail.com

\begin{abstract}
The structural design under seismic loading has been for many years based on force methods to consider the effects of energy dissipation and elastoplastic behavior. Currently, displacement-based methods are being developed to take into account elastoplastic behavior. These methods use moment-curvature relationships to determine the ductility capacity of a structural element, which is the deformation capacity of the element before its collapse. The greater the plastic displacement or rotation a structural member can achieve before it collapses, the more energy it is capable of dissipating. This plastic displacement or rotation capacity of a member is known as the member ductility, which for reinforced concrete members is directly related to efficient concrete confinement. This study investigates at which extents transverse reinforcement detailing influences reinforced concrete column ductility. For this, a bridge located in Ecuador is modeled and analyzed, and its ductility evaluated considering several cases of axial loading and concrete confinement levels. After the performed displacement-based analyses, it is verified whether the response modification factor defined by AASHTO is adequate in the analyzed case.
\end{abstract}

Keywords: seismic resistant structures, reinforced concrete seismic detailing, ductility capacity, plastic dissipation, seismic design of bridges, ductility, displacement-based design.

\section{Resumo}

O projeto estrutural para cargas sísmicas tem sido por muitos anos baseado em métodos de avaliação de forças para considerar os efeitos de dissipação de energia e comportamento elastoplástico. Presentemente métodos baseados em deslocamentos estão em desenvolvimento para a consideração do comportamento elastoplástico. Estes métodos usam relações momento-curvatura para determinar a ductilidade disponível de um elemento estrutural, que é a capacidade de deformação do elemento antes de seu colapso. Neste artigo é apresentada a análise e a avaliação do comportamento de pontes usando métodos baseados em deslocamentos. Para isso, uma ponte localizada no Equador é modelada e analisada e sua ductilidade disponível é verificada considerando-se diversos casos de carga axial e de situações de confinamento do concreto. Uma análise "push-over" é também realizada e os resultados obtidos são comparados.

Palavras-chave: análise sísmica, análise dinâmica, análise sísmica de pontes, dutilidade, projeto baseado em deslocamentos.

Texas A\&M University, Zachry Department of Civil Engineering, College Station, TX, USA;

Universidade Federal do Rio de Janeiro, Escola Politécnica, Departamento de Estruturas, Rio de Janeiro, RJ, Brasil. 


\section{Introduction}

Brazil is located in the center of the South American tectonic plate and, therefore, in a stable geological region with respect to earthquake activity. Nevertheless, earthquakes can also occur within tectonic plates, due to the propagation of waves generated at plate's edges. Seismic stations distributed throughout the Brazilian territory have recently recorded earthquakes of small to medium magnitude. Depending on where is the focus of these earthquakes, and depending on the geotechnical conditions, the seismic waves may present large amplifications, for which the large majority of structures in Brazil are not designed to resist. NBR15421 [1] is the only Brazilian Standard for seismic design and it is specific for buildings. It is then necessary to develop specific criteria for the seismic design of bridges in Brazil.

To design a structure to resist seismic loading considering elastic behavior is clearly uneconomical. For many years the effects of energy dissipation and elastoplastic behavior has been considered based on force methods. These methods use coefficients to reduce the stresses and strains obtained after an elastic seismic analysis. Nowadays, methods based on displacement capacity are being developed and used, and the displacement-based methods fall into this category. In these methods, moment-curvature relationships are used to determine the ductility capacity of structural members. The ductility capacity can be defined as the structura plastic deformation capacity before its collapse. Another way to find a structural member ductility capacity is to perform an approximate non-linear static pushover analysis. Concrete confinement plays an important part in reinforced concrete ductility, there goes the importance of coming up with the appropriate detailing when designing seismic resistant structures, having in mind that appropriate detailing involves the correct distribution, in addition to the correct amount of transverse reinforcement.

\section{Elastoplastic systems}

The accelerations that an earthquake imposes to a structure can be of great intensity, causing significant stresses and strains. Thus, designing a structure to support elastically seismic loads is impractical and uneconomical. The damage must be predicted, which means that the points of plastic hinges formation must be such that it would be possible to perform repairs and avoid global collapse. The equation of motion for elastoplastic systems of a one-degreeof-freedom system is presented in the form of Equation 1, where $u$ is the acceleration, $\zeta$ is the damping ratio, $\omega$ is the circular frequency; $\imath \&$ is the velocity, $\mathrm{u}_{\mathrm{y}}$ is the yield displacement, $f_{s}(u)$ is the inelastic resisting force, $f_{y}$ is the yield strength, and $\ddot{u}_{g}(t)$ is the ground acceleration.

$\ddot{u}+2 \zeta \omega \dot{u}+\omega^{2} u_{y} \frac{f_{s}(u)}{f_{y}}=-\ddot{u}_{g}(t)$

For a given ground acceleration, it is necessary to evaluate the maximum displacement of the elastoplastic system and compare it with the peak displacement $u_{0}$ caused by the same ground acceleration on the corresponding linear elastic system. This system has the same stiffness of the elastoplastic system. Both systems have the same mass and damping and the fundamental frequency of the linear elastic system is the same of the elastoplastic system when subjected to small vibrations (Chopra, [2]).

The normalized yielding strength of the elastoplastic system can be expressed by Equation 2, where $f_{0}$ and $u_{0}$ are the force and deformation peak values due to ground motion on the corresponding elastic system.

$\overline{f_{y}}=\frac{f_{y}}{f_{0}}=\frac{u_{y}}{u_{0}}$

Alternatively, $\overline{f_{y}}$ can be related to $f_{0}$ by the $R_{y}$ coefficient, as displayed in Equation 3. If a system presents $R_{y}$ greater than unity this means that the yielding force is inferior to the minimum required strength for the system remaining in elastic behavior during the ground motion.

$R_{y}=\frac{f_{0}}{f_{y}}=\frac{u_{0}}{u_{y}}$

The absolute peak elastoplastic displacement $u_{m}$, obtained for a certain ground acceleration, can be normalized regarding the yielding displacement $u_{y}$. This dimensionless ratio is called ductility factor $(\mu)$ and it is defined on Equation 4. For systems that deform inelastically, this factor is greater than unity. This factor is the ductility demand imposed on an elastoplastic system by a given ground acceleration. It is a design requirement that the ductile capacity (the ability to deform beyond the elastic limit) must exceed the displacement demand imposed by the earthquake (Chopra, [2]).

$\mu=\frac{u_{m}}{u_{y}}$

Equation 5 shows the relationship between peak deformation $u_{\mathrm{m}}$ and the peak deformation of the correspondent linear system $u_{0}$.

$\frac{u_{m}}{u_{0}}=\frac{\mu}{R_{y}}$

In terms of spectral behavior, for periods greater than the displacement sensitive spectral region, the deformation $u_{m}$ from an elastoplastic system is practically independent from factor $R_{y}$ and is essentially equal to the linear elastic corresponding displacement $u_{0}$. This happens since, for a fixed mass, this system is considerably flexible and the mass stays almost stationary while the base moves. Therefore, the peak deformation is equal to the base displacement, for any value of $\mathrm{R}_{\mathrm{y}^{\text {. }}}$. For systems on the velocity or acceleration sensitive spectral regions, $u_{m}$ can be greater or smaller than $u_{0}$, so the ductility demand $\mu$ can be greater or smaller than $R_{y}$ (Chopra [2]).

\subsection{Concrete confinement}

In the seismic design of bridge piers, there are regions where plastic hinges should be designed for performing with enough ductility in order to prevent total collapse. Adequate member ductility is also required to allow redistribution of forces and energy dissipation. Therefore, it is required that the columns be designed to have enough transverse reinforcement to confine the compressed concrete and to prevent buckling of the longitudinal bars or shear failure. Many studies have shown that efficient concrete confinement results in an increase in strength and ductility. In Mander and Priestley [3], a 
method for determining specific strain limits is proposed. The software CAPIBA, developed by Souza Jr. [4], is based on this method for determining moment-curvature and stress-strain diagrams taking into account concrete confinement; this program was used in this study to find moment-curvature diagrams of the central bridge pier.

\section{Displacement-based seismic design methods}

The displacement-based seismic design methods are based on finding the point of maximum inelastic displacement, in evaluating the energy absorbed during seismic activity, and evaluating the representative total damping in the structure. The displacements are limited in accordance with the intended performance for each structural member. This design method is based on performance concepts. There are some gaps left by force-based design methods which displacement-based methods are able to fill. For instance, the hypothesis that ductile members may reach yielding stress simultaneously considered in force-based methods is better considered in displacement-based methods. Another issue in force-based design methods is that they do not take into account the complexity associated with the calculation of the global ductility of structures.

\subsection{CALTRANS [5]}

CALTRANS [5] recommends a displacement-based procedure. It considers the elastoplastic behavior by introducing a parameter called ductility demand for each type of structural element. The ductility demand is compared to the ductility capacity values of each element of the bridge; then the performance of the bridge can be evaluated. To determine the displacement demand, the analysis must be carried out considering the effective stiffness, taking into account the non-linearity of the material and the cracking effects. The displacement capacity of a structural element is obtained by calculating its rotation capacity, based on the corresponding moment-curvature diagrams. These diagrams should be corrected to an idealized diagram with balanced areas, as shown in Figure 1.

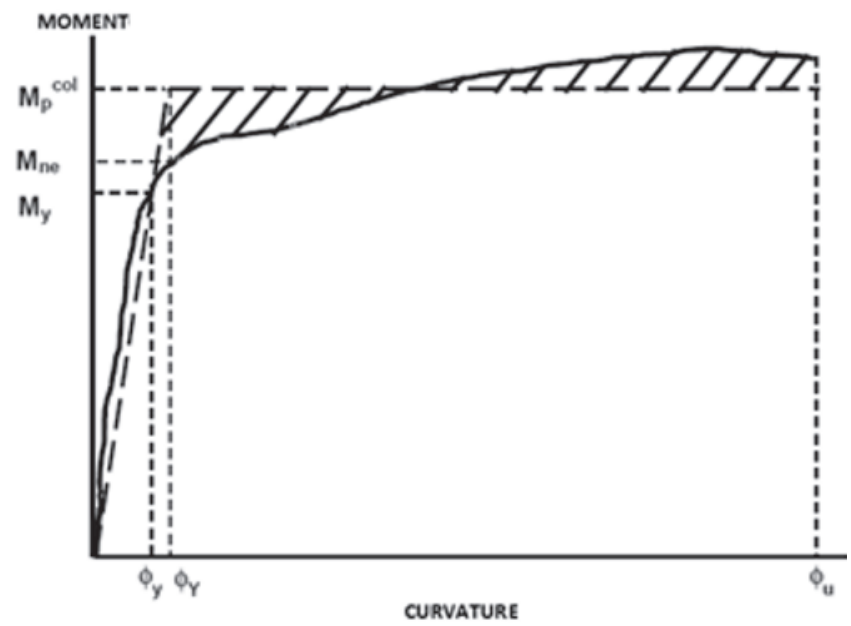

Figure 1

Idealized moment-curvature diagram, CALTRANS [5]
For cantilever columns with fixed base, Equations 6 to 10 can be used to determine the rotation capacity. Equation 11 provides the equivalent analytical plastic hinge length, where $L$ is the distance from the point of maximum moment to the inflection point, $L_{p}$ is the equivalent analytical plastic hinge length as defined by Equation 11 (length in $\mathrm{mm}$, stress in $\mathrm{MPa}$ ). $\Delta_{p}$ is the idealized plastic displacement capacity due to rotation of the plastic hinge; $\Delta_{y}^{\text {col }}$ is idealized yield displacement of the column at the location of the plastic hinge; $\phi_{Y}$ is the idealized yield curvature defined by an elastic-perfectly-plastic representation of the cross section $M-\varnothing$ curve; $\emptyset_{p}$ is the idealized plastic curvature capacity; $\emptyset_{u}$ is the curvature capacity at the Ultimate Limit State; and $\theta_{p}$ is the plastic rotation capacity.

$\Delta_{c}=\Delta_{y}{ }^{c o l}+\Delta_{p}$

$\Delta_{y}{ }^{c o l}=L^{2} / 3 \times \emptyset_{Y}$

$\Delta_{p}=\theta_{p} \times\left(L-L_{p} / 2\right)$

$\theta_{p}=L_{p} \times \emptyset_{p}$

$\emptyset_{p}=\emptyset_{u}-\emptyset_{Y}$

$L_{p}=0.08 L+0.022 f_{y} \emptyset_{b} \geq 0.044 f_{y} \emptyset_{b}$

The local displacement ductility capacity $\mu_{c}$ for a particular member is then defined by Equation 12 and the ductility demand $\mu_{D}$ is determined by Equation 13, where $\Delta_{D}$ is the maximum displacement in an element due to ground motion.

$\mu_{c}=\frac{\Delta_{c}}{\Delta_{y}{ }^{c o l}}$

$\mu_{D}=\frac{\Delta_{D}}{\Delta_{y}{ }^{c o l}}$

\subsection{Nonlinear static pushover analysis}

As stated by Sucuoğlu \& Akkar [6], the concept of seismic performance changes the way in which structures subjected to seismic loading are designed. Instead of increasing the strength, which does not necessarily leads to increased safety, understanding and improving the response of the structure under seismic action is the key. Understanding the distribution of seismic forces along a structure becomes more critical than acknowledging its full value. A good seismic performance is assured when the structure has the ability to form plastic hinges in regions that do not compromise its global stability, dissipating energy before collapsing completely (as stated by Sucuoğlu \& Akkar, [6]).

Through a nonlinear static pushover analysis it is possible to calculate the ductility capacity of structural members considering their elastoplastic behavior. The analysis is performed by subjecting the structure to forces that increase in small amounts up to a certain limit of displacement, the peak response. The analysis must be nonlinear so that it takes into account the elastoplastic effects throughout the process. Sucuoğlu \& Akkar [6] states that the nonlinear structural model allows ductile members to the formation of 
plastic hinges. After the definition of the hinges location and properties, incremental loading static analysis can be performed.

\section{Results and discussions}

In the Case Study, modeling, analysis, and design of a hypothetical bridge located in Ecuador has been performed. The initial design of the pier followed AASHTO [10] provisions. The ductility capacity and demand calculations were performed following the provisions of CALTRANS [5]. SAP2000 [7] FEM program was chosen to model and analyze the bridge. The moment-curvature diagrams were obtained in CAPIBA (Souza Jr., [4]). The ductility capacity and demand were calculated considering three confinement considerations: unconfined; considering transverse reinforcement as prescribed in NBR 6118 [8], referred to as usual detailing; and considering transverse reinforcement as prescribed in $\mathrm{ACl}-318$ [9], referred to as special detailing. Ten cases of compressive forces acting on the pier were considered: maximum and minimum compressive service loads: $9915 \mathrm{kN}$ and $15700 \mathrm{kN}$, and compressive forces of $20000 \mathrm{kN}, 35000 \mathrm{kN}, 50000 \mathrm{kN}, 65000 \mathrm{kN}, 80000 \mathrm{kN}$ $95000 \mathrm{kN}, 115000 \mathrm{kN}$ and $130000 \mathrm{kN}$, arbitrarily defined. These levels of loads were chosen in order to investigate how the progressive increase in the levels of compressive forces affects the member ductility.

In addition, a nonlinear static pushover analysis was performed. Pushover analysis was undertaken for four cases of modeling: three-dimensional model with springs simulating the soil-interaction between the piles and the soil; three-dimensional model and fixed piles; two-dimensional model with springs simulating the soilinteraction between the piles and the soil; and two-dimensional model and fixed piles.

\subsection{Bridge description and additional information}

The bridge presented on this Case Study is hypothetically located in Ecuador. The bridge has two spans with $35.2 \mathrm{~m}$ each. The deck has $13.38 \mathrm{~m}$ in width and it is supported by prestressed concrete

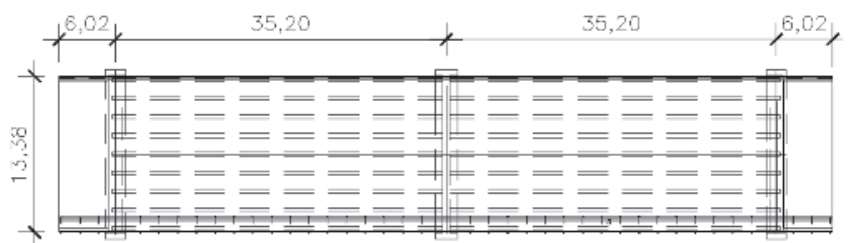

\section{Figure 2}

Plan view of the case study bridge

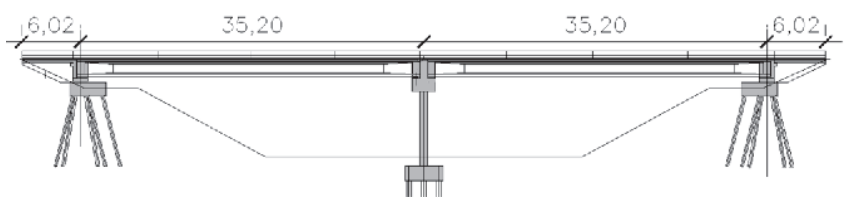

Figure 3

Longitudinal view of the case study bridge girders that are connected to the slabs. Each end of the bridge presents a reinforced concrete abutment wall. The reinforced concrete central pier wall has $8 \mathrm{~m}$ in width and $80 \mathrm{~cm}$ in depth. Figures 2,3 and 4 respectively show a plan view, a longitudinal view of the bridge and a sectional view showing the central pier wall.

\subsection{Finite element modeling}

A three-dimensional modeling of the bridge and its seismic analysis were performed with the finite element program SAP2000 [7]. The abutment and the slabs were represented by shell elements and the girders, center pier and piles by frame elements. Springs arranged along the piles represent the soil-structure interaction; the elastic constants of the springs were determined according to the characteristics of the foundation soil, following the criteria proposed by Terzaghi [11].

Following the prescriptions of AASHTO [10], the analysis performed in order to design the pier was the multimodal elastic, since the bridge presents geometric, mass distribution and stiffness regularity, and it is located on seismic zone 2 (Peak Ground Acceleration equal to $0.3 \mathrm{~g}$ ). The modes to be included in the analysis shall be at least equal to three times the number of bridge spans and also it shall be checked that at least $90 \%$ of the total structure mass was mobilized in each of the three translational directions. Displacements and forces were obtained by combining the response of each mode through the CQC method (Complete Quadratic Combination). The earthquake load combination in each direction (transversal and longitudinal) was made taking $30 \%$ of the transversal earthquake combined to $100 \%$ of the longitudinal earthquake, then $100 \%$ of the transversal earthquake combined to $30 \%$ of the longitudinal one. The purpose of this multimodal analysis has been to obtain the forces for designing the reinforcement of the bridge, to be checked in the subsequent steps of the analysis.

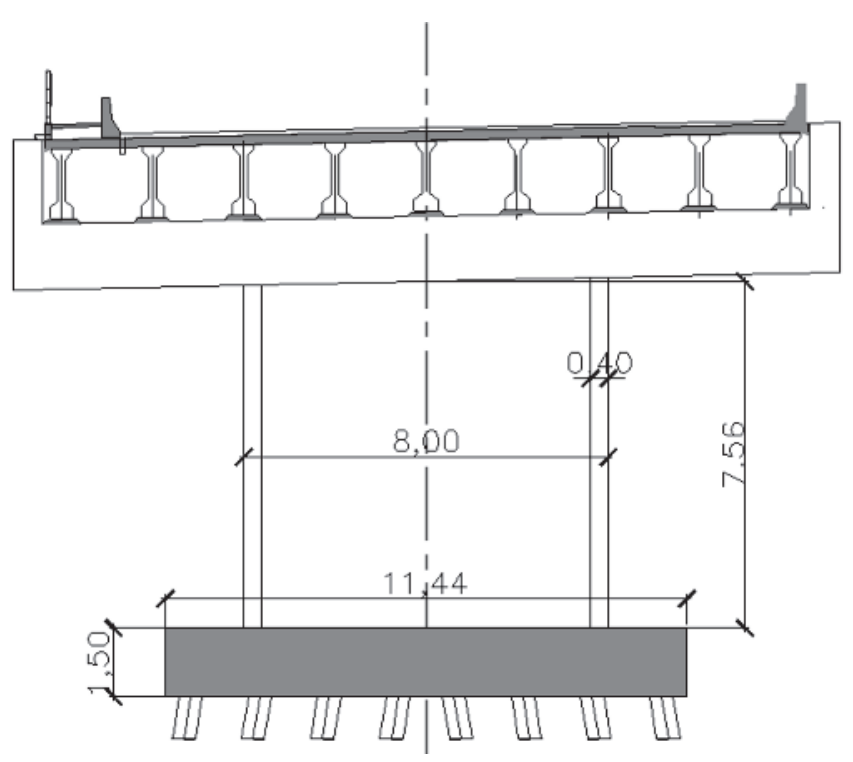

Figure 4

Sectional view showing the central pier wall of the case study bridge 
Table 1

Pier reinforcement summary

\begin{tabular}{|c|c|}
\hline \multicolumn{2}{|c|}{$\mathbf{8 0} \mathbf{c m} \times \mathbf{8 0 0} \mathbf{c m}$ transverse section } \\
\hline $\begin{array}{c}\text { Longitudinal } \\
\text { reinforcement }\end{array}$ & $\begin{array}{c}\Phi 25 \mathrm{~mm} \text { each } 15 \mathrm{~cm} \\
\text { both sides }\end{array}$ \\
\hline $\begin{array}{c}\text { Transverse reinforcement } \\
\text { NBR6118 - usual detailing }\end{array}$ & $\begin{array}{c}\Phi, 3 \mathrm{~mm} \text { each } 20 \mathrm{~cm} \\
8 \text { legged stirrup }\end{array}$ \\
\hline Transverse reinforcement & $\Phi 10 \mathrm{~mm}$ each $12.5 \mathrm{~cm}$ \\
ACl-318 - special detailing & 10 legged stirrup \\
\hline
\end{tabular}

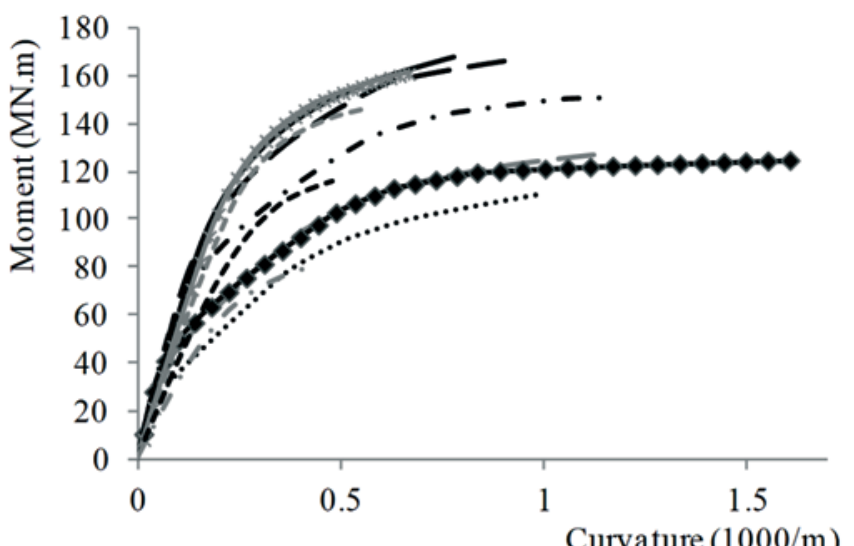

. $\mathrm{Nd}=-9415 \mathrm{kN}$

$\longrightarrow-\mathrm{Nd}=-20000 \mathrm{kN}$

$--\mathrm{Nd}=-50000 \mathrm{kN}$

$\because \mathrm{Nd}=-80000 \mathrm{kN}$

$-\cdot-\cdot-\mathrm{Nd}=-115000 \mathrm{kN}$

Figure 5

Moment-curvature diagrams given by CAPIBA (Souza Jr.
The definition of the considered design spectrum followed the prescriptions of AASHTO [10]. This will result in a bridge designed with low probability of collapse, and that can experience significant damage and discontinuity of operation when subject to earthquakes with 1000 years of return period. As can be verified in Ecuador local seismic maps, the values to be considered for Ss (acceleration coefficient for period of $0.2 \mathrm{~s}$ ) and $\mathrm{S}_{1}$ (acceleration coefficient for period of 1.0s) and PGA (peak ground acceleration) are, respectively, $\mathrm{Ss}=0.725, \mathrm{~S}_{1}=0.255$ and $\mathrm{PGA}$ $=0.3 \mathrm{~g}$. Based on the available site soil information, it was classified as site Class $D$, stiff soil. The $F_{a}, F_{v}$, and FPGA values obtained from AAS$\mathrm{HTO}$ [10] tables are, respectively $\mathrm{F}_{\mathrm{a}}=1.22, \mathrm{~F}_{\mathrm{v}}=1.89$ and $\mathrm{FPGA}=1.20$.

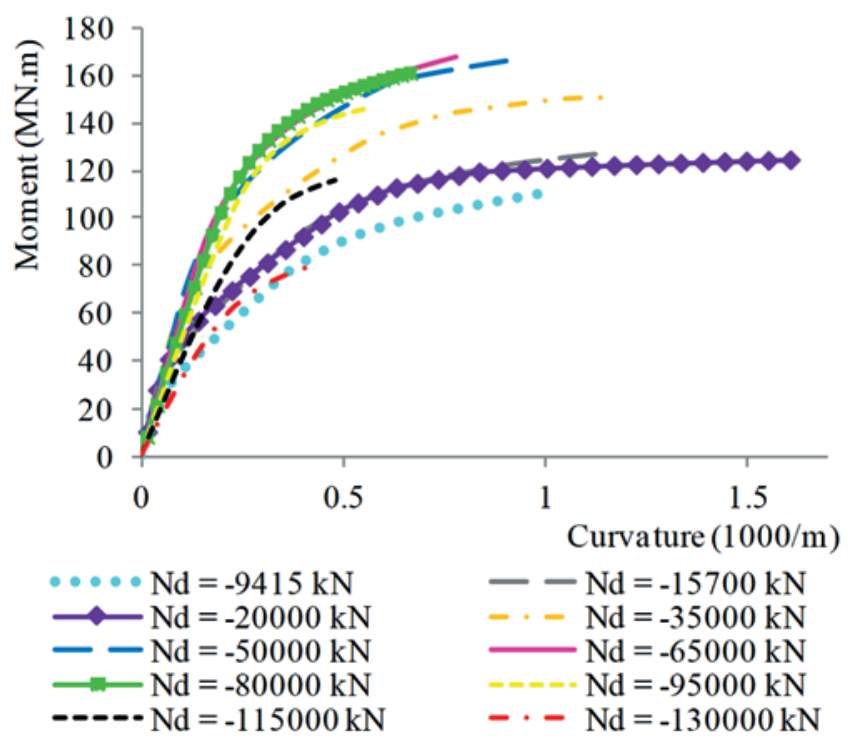

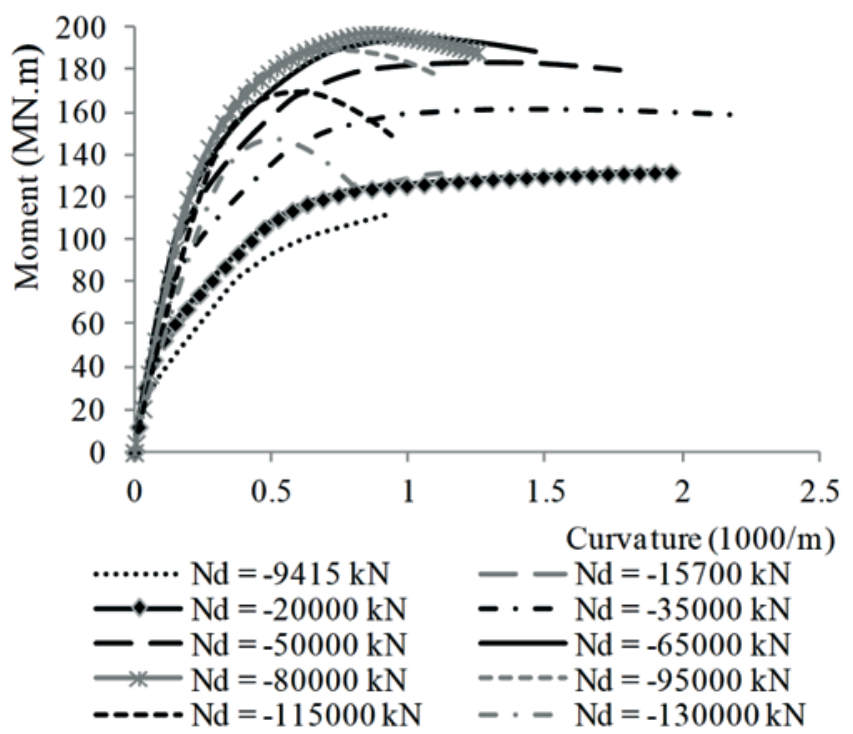

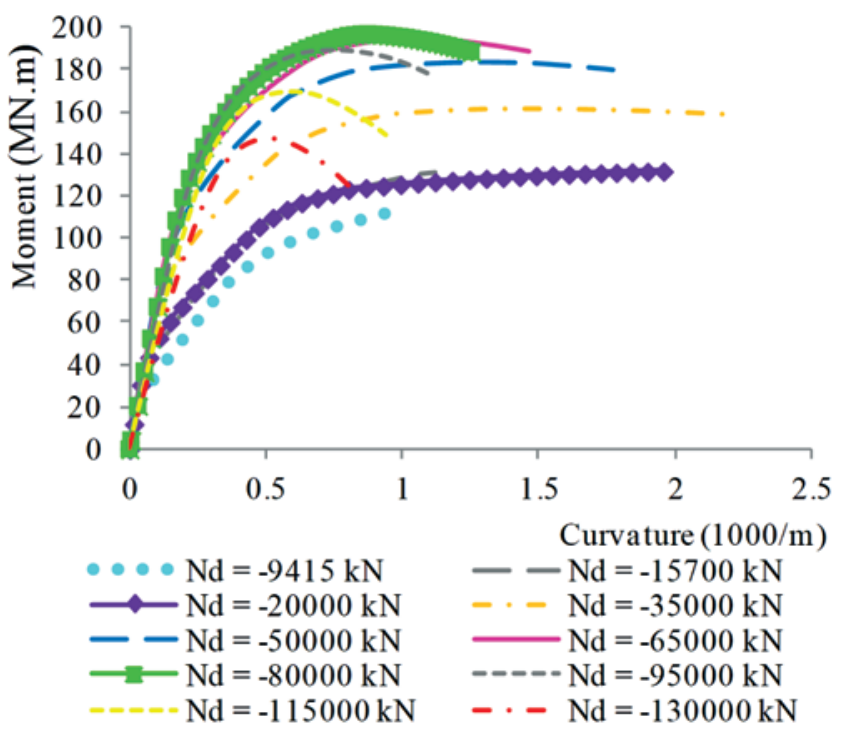

Figure 6

Moment-curvature diagrams given by CAPIBA (Souza Jr. [4]), NBR61 18 [8] transverse reinforcement, concrete confinement considered 

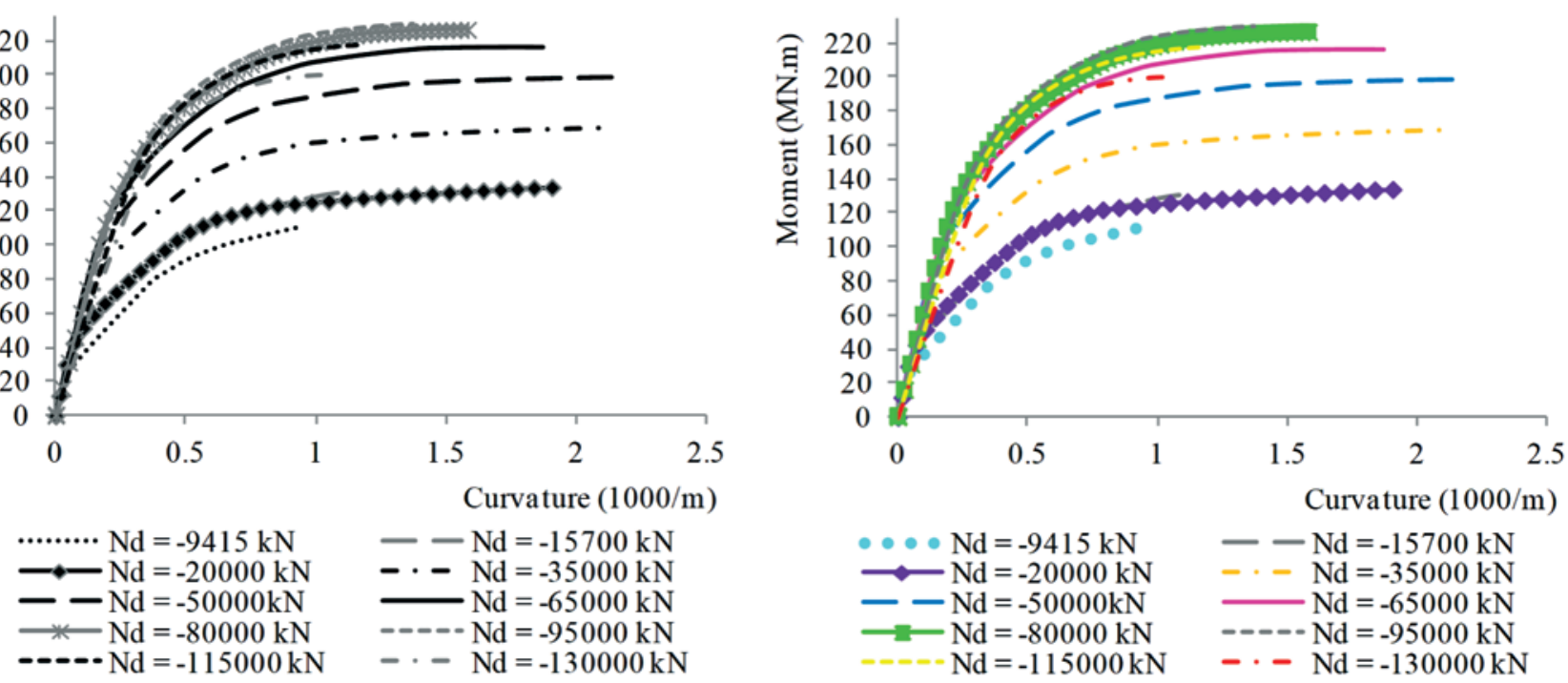

Figure 7

Moment-curvature diagrams provided by CAPIBA (Souza Jr. [4]), ACl-318 [9] transverse reinforcement, concrete confinement considered

To consider the elastoplastic behavior, AASHTO [10] recommends reducing the effects of seismic forces by a response modification factor, since AASHTO is a force-based code. For critical operating class bridges pier walls AASHTO [10] considers a response modification factor of 1.5. Initially the bridge pier was designed following AASHTO [10] provisions, and since this is a force-based code, the response modification factor was applied to reduce the elastic seismic stresses obtained after this analysis. After the pier wall was designed based on this assumption, its ductility capacity was evaluated based on CALTRANS [5] provisions and also by performing a pushover analysis.

\subsection{Design of central pier wall}

Table 1 presents the pier reinforcement summary. The transverse

\section{Table 2}

Ductility capacity, no concrete confinement taken into account

\begin{tabular}{|c|c|c|c|}
\hline & $\mathrm{N}_{\mathrm{d}}(\mathrm{kN})$ & $\eta_{d}$ & $\mu_{c}$ \\
\hline \multirow{10}{*}{ 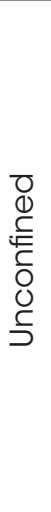 } & -130000 & -0.813 & 1.24 \\
\hline & -115000 & -0.719 & 1.24 \\
\hline & -95000 & -0.594 & 1.32 \\
\hline & -80000 & -0.500 & 1.43 \\
\hline & -65000 & -0.406 & 1.63 \\
\hline & -50000 & -0.313 & 1.97 \\
\hline & -35000 & -0.219 & 2.37 \\
\hline & -20000 & -0.125 & 3.45 \\
\hline & -15700 & -0.098 & 1.92 \\
\hline & -9415 & -0.059 & 1.90 \\
\hline
\end{tabular}

reinforcement was determined by two criteria, corresponding to two levels of detailing and consequent concrete confinement, that influence in ductility capacity. The first criterion is according Brazilian Standard NBR6118 [8] referred to as usual detailing. The second one is according ACl-318 [9] referred to as special transverse detailing.

\subsection{Pier wall ductility assessment according to CALTRANS [5]}

The moment-curvature diagrams obtained in CAPIBA Program (in Souza Jr. [4]) are shown in Figures 5 to 7 . Tables 2 to 4 show the ductility capacity $\mu_{c}$ for all the cases previously defined. Figure 8 shows the relationships between dimensionless compression

\section{Table 3}

Ductility capacity, NBR6118 [8] transverse reinforcement concrete confinement

\begin{tabular}{|c|c|c|c|}
\hline & $\mathrm{N}_{\mathrm{d}}(\mathrm{kN})$ & $\eta_{d}$ & $\mu_{c}$ \\
\hline \multirow{10}{*}{ 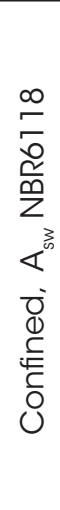 } & -130000 & -0.813 & 1.56 \\
\hline & 15000 ו- & -0.719 & 1.62 \\
\hline & -95000 & -0.594 & 1.83 \\
\hline & -80000 & -0.500 & 2.01 \\
\hline & -65000 & -0.406 & 2.42 \\
\hline & -50000 & -0.313 & 2.96 \\
\hline & -35000 & -0.219 & 3.49 \\
\hline & -20000 & -0.125 & 4.08 \\
\hline & -15700 & -0.098 & 2.00 \\
\hline & -9415 & -0.059 & 2.00 \\
\hline
\end{tabular}




\section{Table 4}

Ductility capacity ACl-318 [9], transverse reinforcement, concrete confinement

\begin{tabular}{|c|c|c|c|}
\hline & $\mathrm{N}_{\mathrm{d}}(\mathrm{kN})$ & $\eta_{d}$ & $\mu_{c}$ \\
\hline \multirow{10}{*}{ 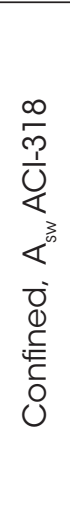 } & -130000 & -0.813 & 1.50 \\
\hline & & -0.719 & 1.62 \\
\hline & -95000 & -0.594 & 1.89 \\
\hline & -80000 & -0.500 & 2.16 \\
\hline & -65000 & -0.406 & 2.69 \\
\hline & -50000 & -0.313 & 3.23 \\
\hline & -35000 & -0.219 & 3.84 \\
\hline & -20000 & -0.125 & 4.66 \\
\hline & -15700 & -0.098 & 2.11 \\
\hline & -9415 & -0.059 & 2.07 \\
\hline
\end{tabular}

forces (obtained by Equation 14) versus ductility capacity. $\eta_{d}=N_{d} /\left(b h f_{c d}^{\prime}\right)$

\subsection{Nonlinear static pushover analysis}

Four types of models where created in order to perform the nonlinear static pushover analysis: three-dimensional model and springs simulating the soil-interaction between the piles and the soil; threedimensional model and fixed piles; two-dimensional model and springs simulating the soil-interaction between the piles and the soil; and two-dimensional and fixed piles. The displacements and ductility capacity are given in Table 5 .

\subsection{Results discussion}

Analyzing the moment-curvature diagrams and the ductility ca- pacity values obtained for unconfined concrete, confined concrete according NBR6118 [8] transverse reinforcement detailing, and confined concrete according ACl-318 [9] transverse reinforcement detailing, it is clear that as the compression on the column increases from $0 \leq \eta \leq-0.13$, ductility capacity increases as well. From certain compressive force values $(\eta \leq-0.13)$, ductility get smaller. For compressive strength values close to rupture $(\eta \leq-0.6)$, ductility becomes very low. It is also noticeable that for $-0.1 \geq \eta \geq 0.5$, there is a considerable enhancement in ductility if the effects of concrete confinement are taken into account. The more confined is the concrete, greater is its ductility. But for $\eta \leq$ -0.5 , increasing the transverse reinforcement does not result in greater ductility capacity.

After performing nonlinear static pushover analyses, it can be seen that for the 4 types of models for which the analysis was performed, ductility capacity increases as the transverse reinforcement increases as well. It is noticeable that two-dimensional models provided results that were very close to results obtained with three-dimensional models. Representing piles by their real length and springs for simulating the soil-structure interaction provides higher ductility values than fixing the piles in the model.

\section{Conclusions}

This study aimed to investigate the influence of reinforcement detailing in ductility of reinforced concrete bridge central pier for different levels of detailing. For this purpose, different sets of reinforced concrete levels of detailing were considered as design and detailing guidelines, based on $\mathrm{ACl} 318$ [9], intermediate, and special detailing, and NBR 6118 [8]- ordinary detailing.

Member moment-curvature relationships were then obtained for each level of detailing, based on Mander's [3] confinement model relations. Once the member moment-curvature diagrams were obtained, member ductility was found by the CALTRANS [5] approximate method and by performing a non-linear pushover analysis. As expected, member ductility reduces as the level of axial compressive forces increases. From the moment-curvature
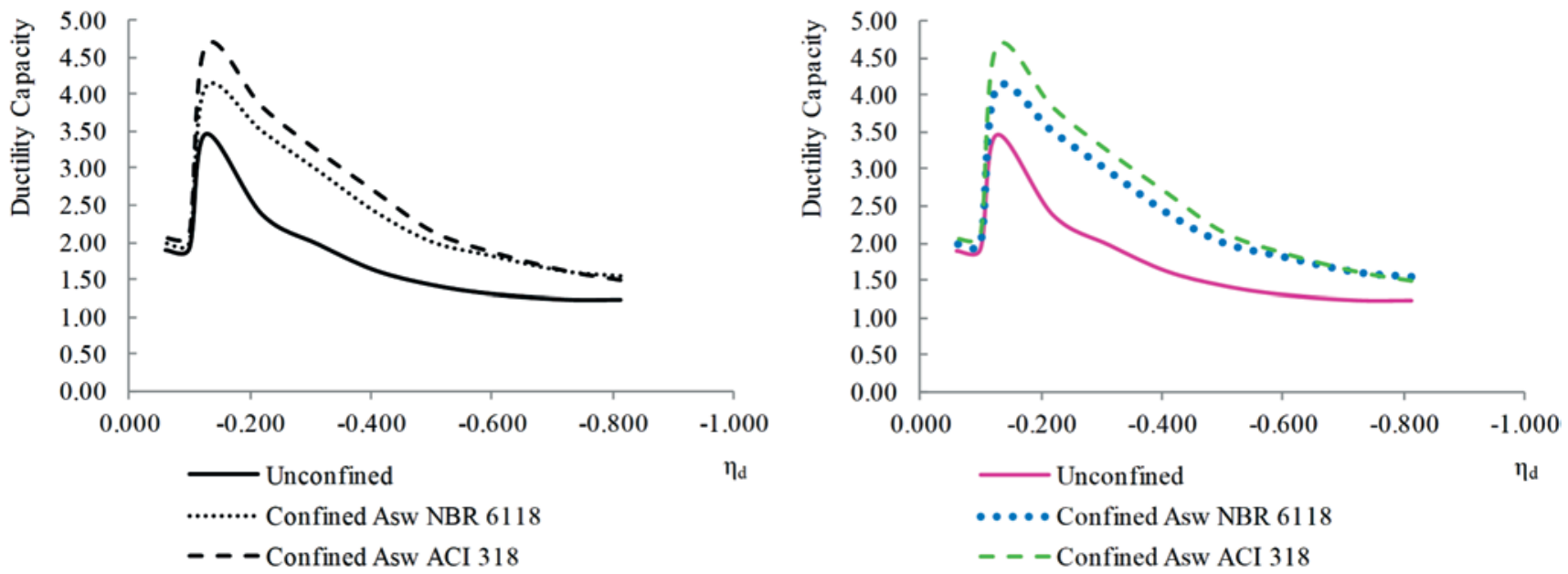

Figure 8

Ductility capacity versus dimension less compressive forces 
Table 5

Ductility capacity after nonlinear pushover analysis on SAP2000 (2014)

\begin{tabular}{|c|c|c|c|}
\hline \multicolumn{4}{|c|}{ Three-dimensional model. Flexible base } \\
\hline \multirow{2}{*}{ Unconfined } & $\mathbf{N}_{\mathrm{d}}(\mathbf{k N})$ & $\eta_{\mathrm{d}}$ & $\boldsymbol{\mu}_{\mathrm{c}}$ \\
\cline { 2 - 4 } & -15700 & -0.098 & 2.72 \\
\cline { 2 - 4 } & -9415 & -0.059 & 2.31 \\
\hline Confined & -15700 & -0.098 & 2.99 \\
\cline { 2 - 4 } $\mathrm{A}_{\mathrm{sw}}$ NBR 6118 & -9415 & -0.059 & 2.77 \\
\hline Confined & -15700 & -0.098 & 3.35 \\
\cline { 2 - 4 } $\mathrm{A}_{\mathrm{sw}}$ ACl-318 & -9415 & -0.059 & 2.91 \\
\hline
\end{tabular}

\begin{tabular}{|c|c|c|c|}
\hline \multicolumn{4}{|c|}{ Two-dimensional model. Flexible base } \\
\hline \multirow{2}{*}{ Unconfined } & $\mathbf{N}_{\mathrm{d}}(\mathbf{k N})$ & $\eta_{\mathrm{d}}$ & $\boldsymbol{\mu}_{\mathrm{c}}$ \\
\cline { 2 - 4 } & -15700 & -0.098 & 2.70 \\
\cline { 2 - 4 } & -9415 & -0.059 & 2.30 \\
\hline Confined & -15700 & -0.098 & 2.96 \\
\cline { 2 - 4 } $\mathrm{A}_{\mathrm{sw}}$ NBR 6118 & -9415 & -0.059 & 2.74 \\
\hline Confined & -15700 & -0.098 & 3.38 \\
\cline { 2 - 4 } $\mathrm{A}_{\mathrm{sw}}$ ACl-318 & -9415 & -0.059 & 2.88 \\
\hline
\end{tabular}

\begin{tabular}{|c|c|c|c|}
\hline \multicolumn{4}{|c|}{ Three-dimensional model. Fixed base } \\
\hline \multirow{2}{*}{ Unconfined } & $\mathbf{N}_{d}(\mathbf{k N})$ & $\eta_{d}$ & $\boldsymbol{\mu}_{\mathrm{c}}$ \\
\cline { 2 - 4 } & -15700 & -0.098 & 2.49 \\
\cline { 2 - 4 } & -9415 & -0.059 & 2.12 \\
\hline Confined & -15700 & -0.098 & 2.72 \\
\cline { 2 - 4 } $\mathrm{A}_{\mathrm{sw}}$ NBR 6118 & -9415 & -0.059 & 2.54 \\
\hline Confined & -15700 & -0.098 & 3.09 \\
\cline { 2 - 4 } $\mathrm{A}_{\mathrm{sw}}$ ACl-318 & -9415 & -0.059 & 2.66 \\
\hline
\end{tabular}

\begin{tabular}{|c|c|c|c|}
\hline \multicolumn{4}{|c|}{ Two-dimensional model. Fixed base } \\
\hline & $\mathrm{N}_{\mathrm{d}}(\mathrm{kN})$ & $\eta_{d}$ & $\mu_{c}$ \\
\hline \multirow{2}{*}{ Unconfined } & -15700 & -0.098 & 2.42 \\
\hline & -9415 & -0.059 & 2.06 \\
\hline \multirow{2}{*}{$\begin{array}{c}\text { Confined } \\
A_{\mathrm{sw}} \text { NBR } 6118\end{array}$} & -15700 & -0.098 & 2.65 \\
\hline & -9415 & -0.059 & 2.45 \\
\hline \multirow{2}{*}{$\begin{array}{c}\text { Confined } \\
A_{s w} A C l-318\end{array}$} & -15700 & -0.098 & 2.99 \\
\hline & -9415 & -0.059 & 2.59 \\
\hline
\end{tabular}

relationships it can be noticed that for certain compression values $(-0.1 \geq \eta \geq-0.5)$, as long as the concrete is sufficiently confined, the strength drop is not abrupt. This can be valuable information when designing a bridge subjected to seismic actions. It is possible to assure a good bridge performance by regulating the compression rate to which the pier is subjected to. As long as the pier compression is in its optimal range, effective confinement assures enough ductility. As long as the pier presents enough plastic deformation capacity, fragile rupture is avoided. It can also be concluded that determining ductility capacity by applying a response modification factor may be too conservative and uneconomical. A pier can achieve greater levels of ductility by adopting special detailing and therefore, at least a different set of response modification factors could be provided by bridge codes, accounting for the level of detailing adopted in the design. Summarizing, concrete piers can achieve ductility levels rather superior than the corresponding to the factors proposed by AASHTO [10], so the response modification values could be revisited, and to different levels of detailing different response modification factors could be defined.

After performing the nonlinear static pushover analysis, it can be seen, as expected, that for the 4 types of models where the analysis was performed, ductility capacity is greater as long as the transverse reinforcement increases. It is noticeable that twodimensional models provided results that were very close to those obtained by three-dimensional models. It can be concluded that the two-dimensional models can present satisfactory results, and the simplified two-dimensional nonlinear static pushover analysis can be adopted to find a member ductility capacity. Representing piles by their real length and springs to simulate the soil-structure interaction results in greater ductility values than the obtained by

fixed piles, which is expected, since the base is more flexible and allows the structure to move more freely. Therefore, it is noticeable that obtaining member displacement capacity by equivalent length fixed piles provides conservative results.

\section{References}

[1] Associação Brasileira de Normas Técnicas, ABNT 2006, NBR-15421: Projeto de estruturas resistentes a sismos Procedimento. Rio de Janeiro: ABNT.

[2] Chopra, A. K. 4th ed. 2012, Dynamics of Structures, Theory and Applications to Earthquake Engineering. Upper Saddle River: Pearson- Prentice Hall.

[3] Mander, J.B.; Priestley, M. J. N., 1988. Theoretical StressStrain Model for Confined Concrete. Journal of Structural Engineering, v.114, n8, pp. 1804-1826.

[4] Souza Jr., P. J., 2012. Análise de Pórticos de Concreto Armado em Condições Sísmicas Considerando o Modelo de Mander. Rio de Janeiro: Universidade Federal do Rio de Janeiro, Escola Politécnica, Programa de Projeto de Estruturas.

[5] California Department of Transportation, CALTRANS 2006, CALTRANS Seismic Design Criteria. California: CALTRANS.

[6] Sucuoğlu, H.; Akkar, S, 1st ed. 2014. Basic Earthquake Engineering from Seismology to Analysis and Design. Cham: Springer.

[7] CSI Computers \& Structures, Inc., SAP2000 v. 16, 2014, Integrated Software for Structural Analysis \& Design. Berkeley: CSI Inc.

[8] Associação Brasileira de Normas Técnicas, ABNT 2014, NBR-6118: Projeto de estruturas de concreto - Procedimento. Rio de Janeiro: ABNT. 
[9] American Concrete Institute, ACl 2014, ACl-318-14: Building Code Requirements for Structural Concrete and Commentary, Farmington Hills: $\mathrm{ACl}$.

[10] American Association of State Highway and Transportation Officials, AASHTO 2010, AASHTO LRFD Bridge Design Specifications. Washington DC: AASHTO, 2010.

[11] Terzaghi, K., 1955. Evaluation of Coefficients of Subgrade Reaction. Géotechnique Journal, v.5, n.4, pp. 297-326, France, 1955. 